\title{
Therapeutic Hypothermia as Effective Therapy For ROSC Patients With Cardiac Arrest: A Systematic Review
}

\author{
Fidiana Kurniawati*, Kili Astarani \\ STIKes RS Baptis Kediri \\ *fidianakurniawati@gmail.com
}

\begin{abstract}
Prehospital cardiac arrest is a relevant cause of death worldwide. The patients who can reach the ROSC (Return of Spontaneous Circulation) phase after experiencing cardiac arrest, only about $10 \%$ can experience improvement and are discharged from the hospital, in addition, only a small proportion can go home with neurological conditions back well. However, there are no studies that reveal when is the right time to implement therapeutic hypothermia, and whether therapeutic hypothermia measures are safe and effective for ROSC patients in cardiac arrest.

This systematic review aimed to identify therapeutic hypothermia as a safe and effective action in post cardiac arrest patients and the appropriate time and temperature for the procedure. This research was taken from the electronic database PubMed, Science Direct, EBSCO, and Google Shcolar, through database scanning, and article screening was carried out independently by researchers. Researchers followed the requirements in fulfilling the inclusion criteria. We used all electronic search strategies for each electronic database according to inclusion data, with search strings: therapeutic hypothermia, prehospital, outof-hospital Cardiac Arrest, randomized controlled trials.

Therapeutic hypothermia is safe and effective for use in ROSC patients with cardiac arrest and the right time to perform this action is at the pre-hospital time with the use of a temperature of $34-36^{\circ} \mathrm{C}$.

Therapeutic hypothermia can be performed pre-hospital with intravenous fluids at a temperature of $34-36^{\circ} \mathrm{C}$ after the patient is resuscitated or during resuscitation, thereby reducing neurological failure due to cardiac arrest.
\end{abstract}

Keywords: Therapeutic Hypothermia, Prehospital, Cardiac Arrest, A Randomized Controlled Trials 


\section{STRADA Jurnal Ilmiah Kesehatan}

DOI: $10.30994 /$ sjik.v9i2.493

ISSN: 2252-3847 (print); 2614-350X (online)

Vol.9 No.2 November 2020 Page.1512-1523

\section{BACKGROUND}

Prehospital cardiac arrest is a relevant cause of death worldwide. According to the American Heart Disease and Stroke Statistics, the survival rate for discharge from hospital after a heart attack is $10 \%$. Furthermore, only a small proportion of patients can go home with neurological conditions back to normal from the hospital. (Mahmoud et al., 2016)

Hypothermia is a state of core body temperature (core) $\leq 35^{\circ} \mathrm{C}$ as a result of the body's inability to retain heat and exposure to cold environments. Hypothermia is associated with physiological changes in all organ systems and has a negative impact if it is not treated quickly and effectively. The body's self-warming mechanism becomes ineffective so that the heart rate and blood pressure are very weak which results in decreased circulation and peripheral pulse, in this case dysrhythmias can occur and other disorders such as hypoxemia and acidosis (Smeltzer, 2014) (Song \& Lyden, 2012)

Based on research, therapeutic hypothermia is a potential life-saving treatment in cardiac arrest patients. Therapeutic hypothermia $\left(33-35^{\circ} \mathrm{C}\right)$ is induced after the return of spontaneous circulation (ROSC) (Kamarainen et al., 2009).Clinical trials in the therapeutic application of hypothermia for 12-24 hours significantly improve survival and neurological outcomes in patients after cardiac resuscitation (Scales et al., 2017). Cardiac arrest patients who remain comatose after ROSC will exhibit ventricular fibrillation (VF) or ventricular tachycardia as the initial heart rhythm. The effects of therapeutic hypothermia include a reduction in cerebral metabolism and the production of oxygen free radicals, a weakening of the immune response during reperfusion and brain edema, but it can also inhibit the release of amino acids. However, what is still unknown is when the right time to treat hypothermia is and how safe and effective it is. (Kuhnke et al., 2019)

In 2011, the National Health Service (NHS) for the National Institute for Health and Care Excellence (NICE) was published in support of the use of therapeutic hypothermia for hypoxic ischemic encephalopathy. NICE also describes guidelines for the use of therapeutic hypothermia in cardiac arrest and has been published in the United States (Nielsen et al., 2013) The American Heart Association recommends hypothermia as the standard of care for patients with ROSC because of insufficient evidence to demonstrate an improvement in patient outcomes from therapeutic hypothermia (Bernard et al., 2012)

\section{METHODS}

This study used a design review analysis method: Systematic Review and in accordance with specific inclusion indicators in document selection through a comprehensive search system (Comprehensive literature search).

Eligibility Criteria in this study was carried out based on inclusion criteria to eliminate and select data. Types of studies using the Randomized Control Trial on the effect of therapeutic hypothermia as a safe and effective action in post cardiac arrest patients. The language used is English, the journal publication year is 2009-2019. Respondents were cardiac arrest patients. The type of intervention was the provision of therapeutic hypothermia in cardiac arrest patients.

\section{Data Search}

Researchers conducted literature searches from electonic databases search, namely PubMed, Science, Direct, EBSCO, and Google Scolar. Researchers used a search string: therapeutic hypothermia, prehospital, out-of-hospital cardiac arrest, randomized controlled trials. Researchers followed the requirements in fulfilling the inclusion criteria. 


\section{STRADA Jurnal Ilmiah Kesehatan}

DOI: $10.30994 /$ sjik.v9i2.493

ISSN: 2252-3847 (print); 2614-350X (online)

Vol.9 No.2 November 2020 Page.1512-1523

\section{Data Collection Process}

Researchers identified data using extraction sheets through the PICO approach (Population, Intervention, Compare, and Outcame). Researchers extracted and checked data. Researchers performed a Critical Appraisal.

\section{Data Items}

The extracted data information includes; 1) Characteristics of respondents including post cardiac arrest patients, 2) Underwent therapeutic hypothermia, 3) At the prehospital location of Out-of-hospital 4) Using the RCT (Randomized Controlled Trials) method. 5) The type of Outcome measured included time and temperature of therapeutic hypothermia.

\section{Data Extraction}

The researchers conducted an independent review of the title including the abstract and full text of the article to extract data according to the inclusion criteria. Data extraction was designed such as publication year, language, study design, characteristics of study population, cooling procedure, time of hypothermic therapy, measurement of outcome.

\section{Risk of Bias}

The researchers validated the literature by extracting data. The researchers identified the research has been carried out according to the procedure or not. Researchers explored the variability in the results of the study (heterogeneity), before conducting the analysis. Researchers identified therapeutic hypothermia according to the research methodology used. Bias Possibility in this study was the difference in the way of action in therapeutic hypothermia in each study.

\section{Study Outcome Definition}

The primary outcome was survival with a good neurologic outcome until the patient was discharged from the hospital or referred for therapy temperature rehabilitation on admission. The outcome measured was the appropriate temperature and timing of hypothermic therapy.

\section{Summary Measures}

The impact of giving hypothermic therapy is to improve the improvement of the condition after ROSC patients. Researchers reviewed 7 articles with the Critical Appraisal Skill Program (CASP), after which data extraction was carried out using the PICO approach to identify the indicators in the article. This Systematic Review was to analyze the effects of a therapeutic hypothermia intervention. Researchers also analyzed the follow-up measures of hypothermic therapy.

\section{RESULT}

\section{Study Selection}

The researcher obtained a total of 7 research articles according to the inclusion criteria. 7 research studies that match the criteria include Kamarainen (2009), Bernard, (2010), Bernard (2012), Nielsen, (2013), Kim, (2017), Mahmoud, (2016) and Scales et al., (2017). Researchers conducted a literature search strategy for NCBI's PubMed, Science Direct and Google Scholar. Total data were obtained using a search string. Initial results obtained 32 data. These data were identified the possibility of duplication and an abstract 


\section{STRADA Jurnal Ilmiah Kesehatan}

DOI: $10.30994 /$ sjik.v9i2.493

ISSN: 2252-3847 (print); 2614-350X (online)

Vol.9 No.2 November 2020 Page.1512-1523

review was carried out whether they matched the research criteria. After the identification of the data, it was obtained 18 suitable data, after that Eligibility was carried out and obtained 12 literatures. The researchers made an in-depth identification of 7 articles and articles that could be used (include).

\section{Characteristics of Included Studies}

It has characteristics, namely based on the research of Bernard, (2010) with the number of respondents 234 pre-hospital adults with cardiac arrest, consisting of 116 people in the control group and 118 people. Risk ratio $0.90,95 \%$ confidence interval 0.70 to 1.17 , $(\mathrm{P}=0.43)$. The results of Bernard's (2012) study with 1198 respondents with cardiac arrest at prehospital. 618 patients under hypothermic therapy and 580 patients with standard prehospital care. Spontaneous circulation in patients receiving cold saline was compared with standard care (41.2\% compared with $50.6 \%, \mathrm{P}=0.03)$.

Kamairen (2009) study of 125 patients underwent cooling and conventional treatment. In the large volume ice cold fluid ( $\mathrm{LVICH})$ treatment group, the volume remained 2 liters.

Cooling Method: Infusion of $4{ }^{\circ} \mathrm{C}$, Ringer's solution of $100 \mathrm{ml} / \mathrm{min}$ in the treatment group versus the control ( $\mathrm{p}<0.0001)$.

In Nielsen, (2013) the number of respondents was 473 patients were given cooling with a temperature of $33^{\circ} \mathrm{C}$ and 466 patients were given cooling with a temperature of $36^{\circ}$ C. Group analysis of temperature was $33^{\circ} \mathrm{C}, 1.06$; $95 \%$ confidence interval [CI], 0.89 to $1.28 ; \mathrm{P}=0.51$ ). Results of analysis for the temperature group $36^{\circ} \mathrm{C}$ (risk ratio, $1.02 ; 95 \%$ $\mathrm{CI}, 0.88$ to $1.16 ; \mathrm{P}=0.78$ ). In this case hypothermic therapy is more effective at $36^{\circ} \mathrm{C}$.

In Kim's study, (2017) with 125 patients, 63 patients received cooling, 62 patients did not get cooling. Infusion of up to $2 \mathrm{~L}$ of $4{ }^{\circ} \mathrm{C}$ normal saline in the field is feasible, safe, and effective in lowering temperature, neurological impact, and ventricular fibrillation rhythm after cardiac arrest.

Based on the results of Mahmoud's research, (2016) with 1391 respondents consisting of groups with a temperature of $32-34^{\circ} \mathrm{C}$ and groups with control of core body temperature. In the intervention group, the cooling temperature was $32-34^{\circ} \mathrm{C}$ and the group with core body temperature control. These results suggested that only mild hypothermia could improve outcomes among patients who had cardiac arrest at prehospital.

According to Scales (2017) in his research on 585 respondents. Consisting of a group with a temperature of $32-34^{\circ} \mathrm{C}$ were 279 respondents and a group with core body temperature control of 306 respondents. Prehospital hypothermia therapy started 5 minutes after ROSC did not lead to improvement of the target temperature of $32-34^{\circ} \mathrm{C}$ in 6 hours, but was safe, and increased the application of TTM (targeted temperature management) in the hospital. 


\section{STRADA Jurnal Ilmiah Kesehatan}

DOI: $10.30994 /$ sjik.v9i2.493

ISSN: 2252-3847 (print); 2614-350X (online)

Vol.9 No.2 November 2020 Page.1512-1523

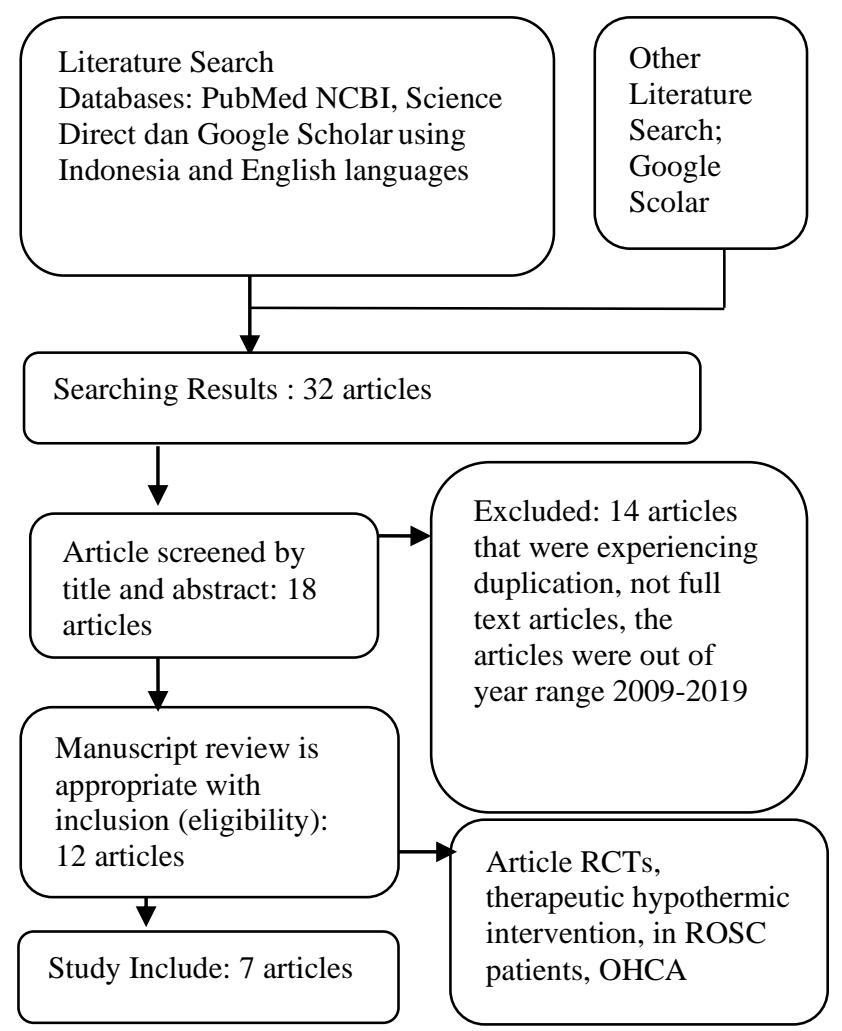

Picture 1. PRISMA flowchart for literature identification

\section{Synthesis of Result}

The results of the synthesis forest plot showed that of the 7 research studies using RCTs, all of them consisted of an intervention group and a control group in respondents with cardiac arrest 
STRADA Jurnal Ilmiah Kesehatan

DOI: $10.30994 /$ sjik.v9i2.493

ISSN: 2252-3847 (print); 2614-350X (online)

Vol.9 No.2 November 2020 Page.1512-1523

Table 1. Data Extraction using the PICO Approach

\begin{tabular}{|c|c|c|c|c|c|c|c|}
\hline $\begin{array}{c}\text { Authors \& } \\
\text { year }\end{array}$ & $\begin{array}{c}\text { Level } \\
\text { JBI }\end{array}$ & Purpose & $\begin{array}{l}\text { Method } \\
\text { (design) }\end{array}$ & Sample & Intervention & Data Analysis & Major Findings \\
\hline $\begin{array}{l}\text { Kamarainen, } \\
(2009)\end{array}$ & III b & $\begin{array}{l}\text { Evaluating recent } \\
\text { clinical studies on } \\
\text { hypothermia induction } \\
\text { after cardiac arrest. } \\
\text { (about cooling level, } \\
\text { safety and } \\
\text { the feasibility of } \\
\text { different methods) }\end{array}$ & $\mathrm{RCT}$ & $\begin{array}{l}\mathrm{N}=125 \\
\text { patients } \\
\text { with } \\
\text { cooling } \\
\text { and } \\
\text { convention } \\
\text { al care }\end{array}$ & $\begin{array}{l}125 \text { patients } \\
\text { Randomized cooling and } \\
\text { conventional treatment. In the } \\
\text { large volume ice cold fluid } \\
\text { (LVICH) treatment group, the } \\
\text { volume remained } 2 \text { liters. } \\
\text { Cooling Method: Infusion of } 4{ }^{\circ} \mathrm{C} \\
\text { Ringer's solution } 100 \mathrm{ml} / \text { menit }\end{array}$ & $\begin{array}{l}\text { The oesophageal temperature decreased } \\
1.24^{\circ} \mathrm{C}(\mathrm{SD} \pm 1.09, \\
\mathrm{n}=54) \text { was observed in the treatment } \\
\text { group compared to the treatment group } \\
0.10^{\circ} \mathrm{C}(\mathrm{SD} \pm 0.94, \mathrm{n}=36) \text { increased in } \\
\text { the control group } \\
(\mathrm{p}<0.0001) .\end{array}$ & $\begin{array}{l}\text { Effective drop } \\
\text { at temperature regardless } \\
\text { of the cooling method }\end{array}$ \\
\hline Bernard, (2010) & III b & $\begin{array}{l}\text { Comparing which one } \\
\text { was more effective in } \\
\text { doing therapeutic } \\
\text { hypothermia after } \\
\text { resuscitation at the pre- } \\
\text { hospital with the time } \\
\text { at the hospital in } \\
\text { cardiac arrest patients }\end{array}$ & RCT & $\begin{array}{l}\mathrm{N}=234 \\
\text { pre- } \\
\text { hospital } \\
\text { adult } \\
\text { patients } \\
\text { with } \\
\text { cardiac } \\
\text { arrest }\end{array}$ & $\begin{array}{l}\text { Of the } 118 \text { patients allocated to } \\
\text { paramedic cooling, } 57 \quad(48 \%) \\
\text { received } 2000 \mathrm{~mL}, 11 \text { received } \\
1500-2000 \mathrm{~mL}, 37 \text { received } 1000- \\
1500 \mathrm{~mL}, 5 \text { received } 500-1000 \\
\mathrm{~mL} \text { considering the length of } \\
\text { transport and } 8 \text { did not receive ice } \\
\text { cold liquid reasons for } \\
\text { administration. Of the } 116 \\
\text { patients allocated to hospital } \\
\text { refrigeration, } 1 \text { received } 2000 \mathrm{~mL} \\
\text { of ice-cold liquid. } \\
\text { Cooling method: Infusion of } 2 \mathrm{~L} \\
\text { of ice-cold lactated Ringer's } \\
\text { solution }\end{array}$ & $\begin{array}{l}\text { Risk ratio } 0.90,95 \% \text { confidence interval } \\
0.70 \text { to } 1.17,(\mathrm{P}=0.43) \text {. }\end{array}$ & $\begin{array}{l}\text { In adults who experienced } \\
\text { cardiac arrest who have } \\
\text { been resuscitated in pre- } \\
\text { hospital with the initial } \\
\text { heart rhythm of ventricular } \\
\text { fibrillation, cooling with } \\
\text { cold / ice intravenous } \\
\text { fluids could reduce heart } \\
\text { rhythm. }\end{array}$ \\
\hline Bernard (2012) & III b & $\begin{array}{l}\text { Compared which ones } \\
\text { most influence CPR on } \\
\text { the incidence of } \\
\text { spontaneous circulation } \\
\text { in cardiac arrest } \\
\text { patients between } \\
\text { hypothermia therapy }\end{array}$ & RCT & $\begin{array}{l}\mathrm{N}=1198 \\
\text { with } \\
\text { cardiac } \\
\text { arrest at } \\
\text { pre } \\
\text { hospital. } \\
618\end{array}$ & $\begin{array}{l}\text { All patients underwent initial } \\
\text { resuscitation care } \\
\text { including defibrillation, } \\
\text { intravenous } \\
\text { cannulation, administration of an } \\
\text { initial dose of epinephrine and } \\
100 \% \text { oxygen } \mathrm{O} 2 \text { ventilation. The }\end{array}$ & $\begin{array}{l}\text { Spontaneous circulation in patients } \\
\text { receiving cold saline was compared } \\
\text { with standard care }(41.2 \% \text { compared with } \\
50.6 \%, \mathrm{P}=0.03) \text {. } \\
\text { Overall } 10.2 \% \text { of patients were allocated } \\
\text { to therapeutic hypothermia while CPR was } \\
\text { alive }\end{array}$ & $\begin{array}{l}\text { In adults with cardiac } \\
\text { arrest at pre-hospital, } \\
\text { induction } \\
\text { hypothermic therapy using } \\
\text { a fast-high volume } \\
\text { infusion, as long as CPR } \\
\text { could reduce the rate of }\end{array}$ \\
\hline
\end{tabular}


STRADA Jurnal Ilmiah Kesehatan

DOI: 10.30994/sjik.v9i2.493

ISSN: 2252-3847 (print); 2614-350X (online)

Vol.9 No.2 November 2020 Page.1512-1523

\begin{tabular}{|c|c|c|c|c|c|c|c|}
\hline $\begin{array}{c}\text { Authors \& } \\
\text { year }\end{array}$ & $\begin{array}{l}\text { Level } \\
\text { JBI }\end{array}$ & Purpose & $\begin{array}{l}\text { Method } \\
\text { (design) }\end{array}$ & Sample & Intervention & Data Analysis & Major Findings \\
\hline & & $\begin{array}{l}\text { using rapid high- } \\
\text { volume infusions, and } \\
\text { the provision of } \\
\text { standard prehospital } \\
\text { care }\end{array}$ & & $\begin{array}{l}\text { patients } \\
\text { under } \\
\text { hypotherm } \\
\text { ic therapy } \\
\text { and } 580 \\
\text { patients } \\
\text { with } \\
\text { standard } \\
\text { prehospital } \\
\text { care } \\
\end{array}$ & $\begin{array}{l}\text { patient then received an infusion } \\
\text { of } 30 \mathrm{~mL} / \mathrm{kg} \text { rapidly and coldly } \\
\text { at a temperature of } 33^{\circ} \\
\text { (maximum } 2 \mathrm{~L} \text { ) via the } \\
\text { intravenous cannula. } \\
\text { Cooling method: Infusion of ice- } \\
\text { cold Ringer's solution }\end{array}$ & $\begin{array}{l}\text { in hospital compared to } 11.4 \% \text { who } \\
\text { received standard care } \\
(\mathrm{P}=0.71) \text {. }\end{array}$ & $\begin{array}{l}\text { return } \\
\text { Spontaneous circulation in } \\
\text { a patient with an initial } \\
\text { nerve rhythm }\end{array}$ \\
\hline Nielsen, (2013) & III b & $\begin{array}{l}\text { Compared the } \\
\text { effectiveness of } 33^{\circ} \mathrm{C} \\
\text { and } 36^{\circ} \mathrm{C} \text { to determine } \\
\text { the target temperature } \\
\text { management for } \\
\text { cooling therapy after } \\
\text { cardiac arrest }\end{array}$ & RCT & $\begin{array}{l}\mathrm{N}=939 \\
\text { was cooled } \\
\text { with a } \\
\text { temperatur } \\
\text { e of } 33^{\circ} \mathrm{C} \\
\text { and } 36^{\circ} \mathrm{C}\end{array}$ & $\begin{array}{l}473 \text { patients were given cooling } \\
\text { with a temperature of } 33^{\circ} \mathrm{C} \text { and } \\
466 \text { patients were given cooling } \\
\text { with a temperature of } 36^{\circ} \mathrm{C}\end{array}$ & $\begin{array}{l}\text { Analysis of temperature groups } 33^{\circ} \mathrm{C} \text {, } \\
1.06 ; 95 \% \text { confidence interval }[\mathrm{CI}], 0.89 \text { to } \\
1.28 ; \mathrm{P}=0.51 \text { ). Analysis results } \\
\text { Temperature group } 36^{\circ} \mathrm{C} \text { (risk ratio, } 1.02 \text {; } \\
95 \% \mathrm{CI}, 0.88 \text { to } 1.16 ; \mathrm{P}=0.78 \text { ). }\end{array}$ & $\begin{array}{l}\text { In an unconscious person } \\
\text { with a heart attack outside } \\
\text { the hospital, it was more } \\
\text { effective to give cooling / } \\
\text { cooling at a temperature of } \\
36^{\circ} \mathrm{C} \text { than a temperature } \\
\text { of } 33^{\circ} \mathrm{C} \text { which did not } \\
\text { provide significant } \\
\text { benefits for the progress of } \\
\text { the patient's condition. }\end{array}$ \\
\hline Kim, (2017) & III $b$ & $\begin{array}{lr}\text { Assessed } & \text { the } \\
\text { feasibility, safety, and } \\
\text { effectiveness } \quad \text { of } \\
\text { prehospital cooling of } \\
4^{\circ} \text { C } & \text { Normal Saline } \\
\text { Rapid } & \text { Infusion. }\end{array}$ & RCT & $\begin{array}{l}\mathrm{N}=125 \\
\text { patients, } \\
63 \text { patients } \\
\text { received } \\
\text { cooling, } 62 \\
\text { patients } \\
\text { did not get } \\
\text { cooling }\end{array}$ & $\begin{array}{l}\text { Randomly, } 125 \text { patients received } \\
\text { standard care without intravenous } \\
\text { cooling. Of the } 63 \text { randomized } \\
\text { patients received cooling } 33^{\circ} \mathrm{C} \\
\text { Cooling Method: } \\
\text { Infusion up to } 2 \mathrm{~L} \text { of ice-cold } \\
0.9 \% \text { saline solution }\end{array}$ & $\begin{array}{l}\text { After cooling, the temperature increase } \\
\text { was } \pm 0.10-0.94^{\circ} \mathrm{C}(\mathrm{P}=0.0001)\end{array}$ & $\begin{array}{l}\text { Infusion of up to } 2 \mathrm{~L} \text { of } 4^{\circ} \\
\mathrm{C} \text { normal saline in the } \\
\text { field was feasible, safe, } \\
\text { and } \\
\text { effective in lowering } \\
\text { temperature, neurological } \\
\text { impact, and ventricular } \\
\text { fibrillation rhythm after } \\
\text { cardiac arrest. }\end{array}$ \\
\hline $\begin{array}{l}\text { Mahmoud, } \\
(2016)\end{array}$ & III b & $\begin{array}{l}\text { Compared between the } \\
\text { targeted temperatures } \\
\text { management } \quad \text { (core }\end{array}$ & $\mathrm{RCT}$ & $\begin{array}{l}\mathrm{N}=1391 \\
\text { consisted } \\
\text { of a group }\end{array}$ & $\begin{array}{l}\text { Respondents consisted of } 2 \\
\text { groups with cooling temperature } \\
32-34^{\circ} \mathrm{C} \text { and groups with core } \\
\end{array}$ & $\begin{array}{l}\text { Insignificant mortality rate (relative risk } \\
\text { [RR] 0.90; 95\% confidence interval [CI], } \\
0.77-1.04 ; \mathrm{P} 1 / 4,15, \mathrm{I} 21 / 434 \% \text { ), surprising }\end{array}$ & $\begin{array}{l}\text { These results suggest that } \\
\text { only mild hypothermia } \\
\text { may be required }\end{array}$ \\
\hline
\end{tabular}


STRADA Jurnal Ilmiah Kesehatan

DOI: $10.30994 /$ sjik.v9i2.493

ISSN: 2252-3847 (print); 2614-350X (online)

Vol.9 No.2 November 2020 Page.1512-1523

\begin{tabular}{|c|c|c|c|c|c|c|c|}
\hline $\begin{array}{c}\text { Authors \& } \\
\text { year }\end{array}$ & $\begin{array}{c}\text { Level } \\
\text { JBI }\end{array}$ & Purpose & $\begin{array}{l}\text { Method } \\
\text { (design) }\end{array}$ & Sample & Intervention & Data Analysis & Major Findings \\
\hline & & $\begin{array}{l}\text { body temperature } 32- \\
\left.34{ }^{\circ} \mathrm{C}\right) \text { with control } \\
(\text { core body temperature } \\
36^{\circ} \mathrm{C} \text { ) in heart failure } \\
\text { patients. The primary } \\
\text { outcome assessed was } \\
\text { all-cause death and } \\
\text { poor neurologic } \\
\text { outcome. }\end{array}$ & & $\begin{array}{l}\text { with a } \\
\text { temperatur } \\
\text { e of } 32-34^{\circ} \\
\text { C and a } \\
\text { group with } \\
\text { control of } \\
\text { core body } \\
\text { temperatur } \\
\text { e. }\end{array}$ & body temperature control. & 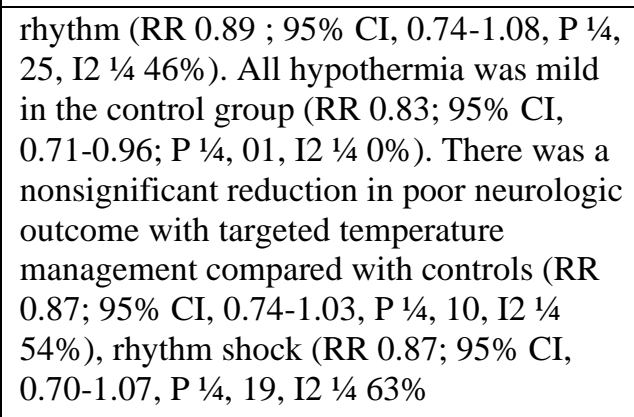 & $\begin{array}{l}\text { improved outcomes among } \\
\text { patients who had heart } \\
\text { attacks in pre-hospital. }\end{array}$ \\
\hline Scales (2017) & III b & $\begin{array}{l}\text { Determine whether pre- } \\
\text { hospital cooling by } \\
\text { paramedics led to } \\
\text { higher 'TTM success' } \\
\text { rates, } \\
\text { defined as attainment } \\
\text { of a target temperature } \\
\text { of } 32-34{ }^{\circ} \text { C within } 6 \\
\text { hours of hospital } \\
\text { arrival }\end{array}$ & RCT & $\begin{array}{l}\mathrm{N}=585 \\
\text { Consist } \\
\text { of the } \\
\text { group with } \\
\text { the } \\
\text { temperatur } \\
\text { e of } 32-34 \\
\circ \quad \mathrm{C} \text { was } \\
279 \text { and } \\
\text { the group } \\
\text { with } \\
\text { control of } \\
\text { core body } \\
\text { temperatur } \\
\text { e was } 306\end{array}$ & $\begin{array}{l}\text { Respondents consisted of } 2 \\
\text { groups with cooling temperature } \\
32-34^{\circ} \mathrm{C} \text { and groups with core } \\
\text { body temperature control. } \\
585 \text { patients were randomized to } \\
\text { receive hypothermic therapy at } \\
\text { prehospital (n=279), control } \\
(\mathrm{n}=306) \text {. Hypothermic therapy did } \\
\text { not increase TTM levels (Pre- } \\
\text { hospital cooling started } 5 \text { minutes } \\
\text { after ROSC did not lead to } \\
\text { improvement in target } \\
\text { temperature 32-34 C within } 6 \\
\text { hours after hospital admission } \\
\text { after OHCA }\end{array}$ & 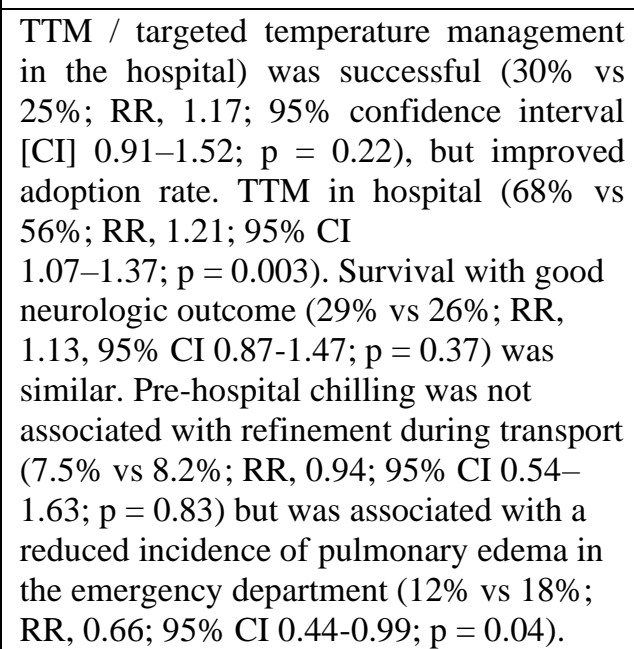 & $\begin{array}{l}\text { Pre-hospital hypothermia } \\
\text { therapy started } 5 \text { minutes } \\
\text { after ROSC did not lead to } \\
\text { improvement of the target } \\
\text { temperature of } 32-34^{\circ} \mathrm{C} \text { in } \\
6 \text { hours, but was safe, and } \\
\text { increased the application } \\
\text { of TTM (targeted } \\
\text { temperature management) } \\
\text { in the hospital. }\end{array}$ \\
\hline
\end{tabular}




\section{STRADA Jurnal Ilmiah Kesehatan}

DOI: $10.30994 /$ sjik.v9i2.493

ISSN: 2252-3847 (print); 2614-350X (online)

Vol.9 No.2 November 2020 Page.1512-1523

\section{DISCUSSION}

In recent years, therapeutic hypothermia is an increasingly used temperature management in the post-resuscitation care of patients with cardiac arrest. TTM / Targeted Temperature Management or hypothermic therapy has been shown to improve survival with good neurological outcomes and is recommended for resuscitated patients.(Scales et al., 2017) Unconscious patients admitted to the critical care unit after prehospital heart attack are at high risk for death, and neurologic deficits are frequent among those who survive. Therapeutic hypothermia (also called target temperature management) is now recommended in international resuscitation guidelines.(Bernard et al., 2012)

The American Heart Association, International Liaison Committee on Resuscitation, and other international agencies now highly recommend TTM for eligible patients following resuscitation from a heart attack. Despite these recommendations, TTM was administered inconsistently, incompletely, and often with delay. The reasons are due to awareness of recommended practices, perceptions of poor prognosis, limited time and resources, and lack of manpower. (Scales et al., 2017)

Out of hospital heart attack (OHCA) after return of spontaneous circulation (ROSC). Whereas the mechanism is not fully understood, a decrease in core body temperature might reduce the inflammatory response that occurs after reperfusion ischemic injury, directly reduce cellular injury, and increase brain neuronal healing and oxygen demand by reducing intracranial pressure.(Song \& Lyden, 2012)

Pre-hospital cooling interventions by emergency medical service providers (EMS) (paramedics) can act as a catalyst to drive more timely application of TTM by hospital doctors, and pre-cooling can also improve clinical outcomes (Bernard et al., 2010). Randomized controlled trials (RCTs) with cold intravenous saline, and other applications have been shown to be more helpful to victims than no prehospital cooling.

Many treatments provide benefits for therapeutic hypothermia after heart failure. This mechanism is thought to affect all Level 3 injuries after cardiac arrest: ischemic injury, direct reperfusion injury, and delayed reperfusion injury.

The study characteristics of the 7 studies that were obtained all examined the use of the cooling method in cardiac arrest patients undergoing ROSC. Before cooling (cooling), the patient must first be resuscitated. The research management site was homogeneous, namely the pre-hospital cooling action (OHCA). All studies used the RCTs (Randomized Control Trial) design. There are 4 studies comparing the effectiveness of management in patients after cardiac arrest using cooling with conventional measures, namely the management of standard pre-hospital cardiac arrest treatments such as drug administration, CPR and so on in patients. There are 2 studies comparing the use of cooling with a temperature range of $32-34^{\circ} \mathrm{C}$ with a core body temperature of $36^{\circ} \mathrm{C}$. The infusions used include Infusion of ice-cold Ringer's solution, Infusion of $4^{\circ}$ Ringer's acetate, and Infusion of $4^{\circ}$ normal saline. All studies conducted blinked respondents. The timing of therapeutic hypothermic management was at the time of prehospital CPR.

Bernard et al. (2012) cooled all patients undergoing initial resuscitation treatment including defibrillation, intravenous cannulation, administration of an initial dose of epinephrine and $\mathrm{O} 2$ ventilation of $100 \%$ oxygen. The patient then received an infusion of $30 \mathrm{~mL} / \mathrm{kg}$ rapidly and coldly at a temperature of $33^{\circ}$ (maximum $2 \mathrm{~L}$ ) through an intravenous cannula: Infusion of ice-cold Ringer's solution, and the other group had only pre-hospital cardiac arrest management according to standard without cooling treatment. From the results, it was found that crdiac arrest experienced in adults, after induction with hypothermic therapy during $\mathrm{CPR}$, can trigger a return of spontaneous circulation and 


\section{STRADA Jurnal Ilmiah Kesehatan}

DOI: $10.30994 /$ sjik.v9i2.493

ISSN: 2252-3847 (print); 2614-350X (online)

Vol.9 No.2 November 2020 Page.1512-1523

restore the patient's heart rhythm back to a normal rhythm. The timing of therapeutic hypothermia management is during pre-hospital resuscitation.

Based on research by Bernard et al., (2010) by comparing which one was more effective in doing therapeutic hypothermia after resuscitation while in pre-hospital with when in hospital in cardiac arrest patients. Of the 118 patients $57(48 \%)$ received $2000 \mathrm{~mL}$, 11 received $1500-2000 \mathrm{~mL}, 37$ received $1000-1500 \mathrm{~mL}, 5$ received $500-1000 \mathrm{~mL}$, the amount of fluid was influenced by the length of transportation from the scene to the hospital. Meanwhile, 116 patients were cooled down in the hospital. From this study, what distinguishes was the management time of giving hypothermia therapy, namely at the prehospital and at the hospital. The results obtained that giving resuscitation and hypothermic therapy were more effective at reducing heart rhythm in the state of ventricular fibrillation compared to tuning at the hospital. The timing of therapeutic hypothermia management was during prehospital resuscitation.

The results of a study conducted by Kim et al. (2017) examined the feasibility, safety, and benefits of prehospital care for hypothermia. OHCA patients with cardiac arrest were randomized to rapid prehospital cooling to an infusion of $4{ }^{\circ} \mathrm{C}$ normal saline. The hospital temperatures differed significantly $(p<0.0001)$. This study presented survival outcomes based on the VF and non-VF heart rhythm groups. This cooling method is not associated with side effects in terms of hemodynamic instability, nor with other clinical measures such as pulmonary edema assessed by chest X-ray or arrest. Although these results indicated that this cooling method was safe to perform in patients after resuscitation. The timing of therapeutic hypothermia management was during prehospital resuscitation.

Another study by Nielsen et al., (2013) compared the effectiveness of cooling with a temperature of $33^{\circ} \mathrm{C}$ and $36^{\circ} \mathrm{C}$ to determine the target temperature management for cooling therapy after cardiac arrest. Of the 473 patients who were given cooling with a temperature of $33^{\circ} \mathrm{C}$ and 466 patients were given cooling at a temperature of $36^{\circ} \mathrm{C}$, the results showed that people who were unconscious with a heart attack in situations outside the hospital were more effective at cooling at $36^{\circ} \mathrm{C}$ than at $33^{\circ} \mathrm{C}$. The temperature that tended to be lower did not provide a significant benefit for the progress of the patient's condition. The timing of therapeutic hypothermia management was during pre-hospital resuscitation.

Research by Nielsen et al., (2013) is also supported by research conducted by Mahmoud et al., (2016). The study compared cooling with a temperature of $32-34{ }^{\circ} \mathrm{C}$ with cooling (core body temperature of $36^{\circ} \mathrm{C}$ ) in patients with heart failure.

The primary outcome assessed among these was cause of death and poor neurological outcome. The results obtained from mild hypothermia were necessary and may improve outcomes among pre-hospital heart attack patients. So that cooling with a mild temperature of $36^{\circ} \mathrm{C}$ showed more impact on neurological, ROSC patients. The timing of therapeutic hypothermia management was during pre-hospital resuscitation.

Characteristics of included studies that were the characteristics of the 7 eligible studies were summarized in research published between 2009 and 2019, and all of them were RCTs. Of the six studies, 2 were conducted in Europe, 2 in North America and the USA, 23 and 1 in Finland and 1 in Australia. All studies were published in English. Heart rhythms in three studies were ventricular fibrillation (VF) and non-VF, one was VF, and the last was non-VF. In one study, therapeutic hypothermia was initiated before ROSC, and in another, after ROSC. Two studies induced therapeutic hypothermia by infecting $\mathrm{NSl} 4^{\circ} \mathrm{C} 23$ solution or Ringer's acetate solution, two studies with cold Ringer's solution. 


\section{STRADA Jurnal Ilmiah Kesehatan}

DOI: $10.30994 /$ sjik.v9i2.493

ISSN: 2252-3847 (print); 2614-350X (online)

Vol.9 No.2 November 2020 Page.1512-1523

All studies used blink of respondents, both patients and health workers who performed therapeutic hypothermia, so as to reduce bias. All respondents in the study had a large enough sample to reduce bias in the study.

Safety of intravenous cold fluids infusion to induce therapeutic hypothermia at prehospital (Kim et al., 2017) The results of respondents randomized / randomized treatment with therapeutic hypothermia, patients discharged from the hospital after experiencing cardiac arrest, will be more effective because it is minimal in neurological impact, compared to conventional management, namely $\mathrm{CPR}$, pharmacodynamic resuscitation measures.

The quality of research in this systematic review is good, it is shown that all studies report the criteria desired by researchers, besides that the number of respondents is large. After searching the literature, all data met the requirements, the patient data were treated with therapeutic hypothermia at the pre-hospital, temperature, fluids used and the mean 95\% CI results were converted to mean \pm SD by the formula method. All studies reported similar results on hospital admissions and patient survival after pre-hospital to hospital.

There were no significant differences regarding safety outcomes or secondary outcomes such as neurologic outcomes and mortality in patients with ROSC. There are also those who do not. The results of the study of Kamarainen et al. (2009) showed statistically significant with respect to survival for hospital discharge and favorable outcome at hospital. A drawback in this study was an unobserved rearrest rate of increase, further related to the side effects of hemodynamic instability in ROSC patients.

Based on the results of the seven studies, it shows that the effective time to do prehospitalization is when resuscitation helps in cardiac arrest, and does not have to wait for ROSC patients. Therapeutic hypothermic action is safe and effective based on the results of existing research, so this action can be recommended for emergency management of patients with cardiac arrest, this action is also effective because it does not require a lot of money so that it can reduce the financial burden borne by the patient

\section{CONCLUSION}

Therapeutic hypothermia is safe and effective for use in ROSC patients with cardiac arrest and the right time to perform this action is during pre-hospital resuscitation. Therapeutic hypothermia measures can be done during resuscitation, not having to wait for successful resuscitation actions / ROSC. Therapeutic hypothermia can be performed pre-hospital with intravenous fluids at a temperature of $34^{\circ}-36^{\circ} \mathrm{C}$ so as to reduce neurological failure due to cardiac arrest.

\section{REFERENCES}

Bernard, S. A., Smith, K., Cameron, P., Masci, K., Taylor, D. M., Cooper, D. J., Kelly, A. M., \& Silvester, W. (2010). Induction of therapeutic hypothermia by paramedics after resuscitation from out-of-hospital ventricular fibrillation cardiac arrest: A randomized controlled trial. $\quad$ Circulation, $122(7), \quad 737-742$. https://doi.org/10.1161/CIRCULATIONAHA.109.906859

Bernard, S. A., Smith, K., Cameron, P., Masci, K., Taylor, D. M. D., Cooper, D. J., Kelly, A. M., Silvester, W., Patrick, I., Fitzgerald, M., Wright, C., Buist, M., Dixon, B., Ernest, D., Botha, J., Duke, G., \& Mulholland, E. (2012). Induction of prehospital therapeutic hypothermia after resuscitation from nonventricular fibrillation cardiac arrest*. Critical Care Medicine, 40(3), 747-753. https://doi.org/10.1097/CCM.0b013e3182377038 


\section{STRADA Jurnal Ilmiah Kesehatan}

DOI: $10.30994 /$ sjik.v9i2.493

ISSN: 2252-3847 (print); 2614-350X (online)

Vol.9 No.2 November 2020 Page.1512-1523

Kamarainen, A., Virkkunen, I., Tenhunen, J., Yli-Hankala, A., \& Silfvast, T. (2009). Prehospital therapeutic hypothermia for comatose survivors of cardiac arrest: A randomized controlled trial. Acta Anaesthesiologica Scandinavica, 53(7), 900-907. https://doi.org/10.1111/j.1399-6576.2009.02015.x

Kim, F., Nichol, G., Maynard, C., Hallstrom, A., Kudenchuk, P. J., Rea, T., Copass, M. K., Carlbom, D., Deem, S., Longstreth, W. T., Olsufka, M., \& Cobb, L. A. (2014). Effect of prehospital induction of mild hypothermia on survival and neurological status among adults with cardiac arrest a randomized clinical trial. JAMA - Journal of the American Medical Association, 311(1), 45-52. https://doi.org/10.1001/jama.2013.282173

Kuhnke, M., Albrecht, R., Schefold, J. C., \& Paal, P. (2019). Successful resuscitation from prolonged hypothermic cardiac arrest without extracorporeal life support: A case report. Journal of Medical Case Reports, 13(1), 19-22. https://doi.org/10.1186/s13256-019-2282-6

Mahmoud, A., Elgendy, I. Y., \& Bavry, A. A. (2016). Use of Targeted Temperature Management after Out-of-hospital Cardiac Arrest: A Meta-Analysis of Randomized Controlled Trials. American Journal of Medicine, 129(5), 522-527.e2. https://doi.org/10.1016/j.amjmed.2015.11.004

Nielsen, N., Wetterslev, J., Cronberg, T., Erlinge, D., Gasche, Y., Hassager, C., Horn, J., Hovdenes, J., Kjaergaard, J., Kuiper, M., Pellis, T., Stammet, P., Wanscher, M., Wise, M. P., An̊eman, A., Al-Subaie, N., Boesgaard, S., Bro-Jeppesen, J., Brunetti, I., ... Friberg, H. (2013). Targeted temperature management at $33^{\circ} \mathrm{c}$ versus $36^{\circ} \mathrm{c}$ after cardiac arrest. New England Journal of Medicine, 369(23), 2197-2206. https://doi.org/10.1056/NEJMoa1310519

Scales, D. C., Cheskes, S., Verbeek, P. R., Pinto, R., Austin, D., Brooks, S. C., Dainty, K. N., Goncharenko, K., Mamdani, M., Thorpe, K. E., \& Morrison, L. J. (2017). Prehospital cooling to improve successful targeted temperature management after cardiac arrest: A randomized controlled trial. Resuscitation, 121, 187-194. https://doi.org/10.1016/j.resuscitation.2017.10.002

Smeltzer. (2014). Brunner \& Suddarth's Textbook of Medical- Surgical Nursing (13th ed.). Lippincott Williams \& Wilkins.

Song, S. S., \& Lyden, P. D. (2012). Overview of therapeutic hypothermia. Current Treatment Options in Neurology, 14(6), 541-548. https://doi.org/10.1007/s11940012-0201-x 